University of Nebraska - Lincoln

DigitalCommons@University of Nebraska - Lincoln

USDA Forest Service / UNL Faculty Publications U.S. Department of Agriculture: Forest Service -National Agroforestry Center

2009

Determinants of Trust for Public Lands: Fire and Fuels

Management on the Bitterroot National Forest

\author{
Adam Lijeblad \\ National Forest Foundation \\ William T. Borrie \\ College of Forestry and Conservation
}

Alan E. Watson

Aldo Leopold Wilderness Research Institute

Follow this and additional works at: https://digitalcommons.unl.edu/usdafsfacpub

Part of the Forest Sciences Commons

Lijeblad, Adam; Borrie, William T.; and Watson, Alan E., "Determinants of Trust for Public Lands: Fire and Fuels Management on the Bitterroot National Forest" (2009). USDA Forest Service / UNL Faculty Publications. 66.

https://digitalcommons.unl.edu/usdafsfacpub/66

This Article is brought to you for free and open access by the U.S. Department of Agriculture: Forest Service -National Agroforestry Center at DigitalCommons@University of Nebraska - Lincoln. It has been accepted for inclusion in USDA Forest Service / UNL Faculty Publications by an authorized administrator of DigitalCommons@University of Nebraska - Lincoln. 


\title{
Determinants of Trust for Public Lands: Fire and Fuels Management on the Bitterroot National Forest
}

\author{
Adam Lijeblad • William T. Borrie • \\ Alan E. Watson
}

Received: 13 March 2008/Accepted: 25 October 2008/Published online: 25 November 2008

(C) U. S. Government 2008

\begin{abstract}
Management of public lands occurs today with high levels of scrutiny and controversy. To succeed, managers seek the support, involvement, and endorsement of the public. This study examines trust as an indicator of managerial success and attempts to identify and measure the components that most influence it. A review of trust literature yielded 14 attributes that were hypothesized to contribute to trust, grouped into the three dimensions of Shared Norms and Values, Willingness to Endorse, and Perceived Efficacy. Operationalizing these attributes and dimensions, a telephone survey was administered to a sample of Montana, USA, residents living adjacent to the Bitterroot National Forest $(n=1,152)$. Each of the attributes was measured in the context of federal lands fire and fuel management. Structural equation modeling showed that all 14 attributes were found to be influential contributors to levels of trust. Results suggest that if managers are to maintain or increase levels of public trust, they need to consider each of trust's attributes as they make social, ecological, and economic resource decisions.
\end{abstract}

Keywords Trust - Shared values - Public involvement . Collaboration · Fire and fuels management .

Bitterroot National Forest

A. Lijeblad

National Forest Foundation, Building 27, Suite 3, Fort Missoula

Road, Missoula, MT 59804, USA

W. T. Borrie ( $\square)$

College of Forestry and Conservation, University of Montana,

32 Campus Drive, Missoula, MT 59812, USA

e-mail: bill.borrie@umontana.edu

A. E. Watson

Aldo Leopold Wilderness Research Institute, 790 E. Beckwith, Missoula, MT 59801, USA
Trust has been receiving increased attention by public lands managers and scientists over the last several years. It is one of the most influential factors in the success or failure of relationships of all kinds. When trust is present, parties are linked by social bonds and shared commitments and are able to interact openly and honestly. When trust is deficient, parties lack the bonds that permit open, honest communication, and generally resort to defensive, confrontational, or insular behavior.

It is not uncommon to hear anecdotal remarks of members of the public that do not trust public lands management agencies, interest groups that do not trust opposing interest groups, employees in one branch of an agency that do not trust employees in another branch or another agency, and of interest groups that do not trust certain branches of an agency - and so on. While many times the prevalence of remarks such as these reflect an apparent sea of distrust in public lands management, a number of studies generally suggest otherwise (Cvetkovich and Winter 2004; Shindler and Toman 2003; Winter and others 1999, 2004; Winter and Cvetkovich 2003). There is a range of trust exhibited by the public in most public lands management contexts.

Researchers have recently suggested that public land managers pay increased attention to the level of public trust, with the expectation that attending to trust levels can increase the effectiveness of meeting resource management objectives. Lachapelle and others (2003) suggest that a lack of trust is one of the primary barriers that impede natural resource decisionmaking. Similarly, Davenport and others (2007) suggest that trust is often tenuous in local communities, thus limiting the potential for collaborative processes.

While numerous studies in the field of natural resource management have attempted to measure trust levels in 
some form (Borrie and others 2002; Cvetkovich and Winter 2003, 2004; Shindler and Toman 2003; Winter and Cvetkovich 2003; Winter and others 1999), or signal the importance of trust as a finding in their research (Winter and others 2002; Leahy and others 2004; Lachapelle and others 2003; Shindler and others 2002), none are known to have comprehensively examined trust. The work by Winter and colleagues is among the most in-depth trust research in the public lands management field, and bases measures of trust on the perceived similarity of respondents' salient values with those of a managing agency (Cvetkovich and Winter 2003, 2004; Winter and Cvetkovich 2003; Winter and others 1999). However, Davenport and others (2007) documented that trust in the context of natural resource management is more complex than a single perspective such as shared values. Indeed, approaches to understanding trust from outside the realm of public lands management suggest that a more complex framework for examining trust is needed. Previous research on trust from the fields of marketing (Ganesan and Hess 1997), management (Mayer and others 1995; Rousseau and others 1998; Sheppard and Sherman 1998), risk analysis (Peters and others 1997; Sjöberg 2001), psychology (Kramer 1999), and public administration (Thomas 1998) all suggests that there is more to trust than merely sharing a group of important values with another party, and that trust is composed of many facets. Building on the work of Winter and others (2004), this study draws on the trust literature from these other fields and disciplines to paint a broad portrait of trust, and then uses this framework to gain a better understanding of trust in public lands management. Our purpose is to describe and empirically confirm the existence of three broad dimensions of trust and 14 contributors to the public's trust, using the context of fire and fuels management at the Bitterroot National Forest (BNF).

\section{An Interdisciplinary Approach to Trust}

In 1970, Kee and Knox stated that, across and within disciplines, researchers were being challenged to conceptualize and define trust. More than three decades later, this challenge continues, and in the trust literature there is still no generally agreed-upon definition or conceptualization of trust (Kramer 1999). The present study adopts a basic premise of trust as a context-specific psychological state. Following Hardin's (1993) model, there are three components to any trusting relationship: a trustor, a trustee, and a specific context in which they interact. Collectively, these three components interact and define the level of trust in a relationship. The trustor and trustee both rely on individual assessments of the specific situation when deciding on the degree of trust to extend. The context of situations, such as what is at stake, personal power differences in a relationship, risk perception, and alternatives to the relationship are all important, since they determine the consequences that may occur by extending trust (Mayer and others 1995). If the consequences of trust are too great or the risk is too high, a trusting relationship may not develop fully.

This research adopts the definition of trust proposed by Mayer and others (1995), that trust is "the willingness of a party to be vulnerable to the actions of another party based on the expectation that the other will perform a particular action important to the trustor, irrespective of the ability to monitor or control that other party" (p. 712). Risk is inherent in trusting others, but with this definition, trusting should be viewed not as taking a risk but rather as being willing to take a risk. That is, while there can be risk without trust, there cannot be trust without risk. If one is not vulnerable, there is no need to trust others. However, in modern society it is next to impossible to make oneself completely invulnerable to the actions of others. Where trust is absent, parties tend to rely more heavily on contracts and the rule of law to reduce their exposure to risk.

Trust is acknowledged to be a complex or multiplex phenomenon that is readily open to interpretation (Ganesan and Hess 1997; Kramer 1999; Levi 2000; Rousseau and others 1998). One-dimensional portraits of trust, such as the Salient Values Similarity model developed by Earle and Cvetkovich (1995), may not be sufficient to fully represent trust as an attitude because they do not account for other components of trust that are now identified in the trust literature. Especially when attempting to measure trust in complex situations, unidimensional representations are not as capable of accounting for the intricacies of trusting relations and they yield less insight into the internal dynamics of trust. More comprehensive, multidimensional measures of trust can provide more valid and reliable portrayals.

\section{Hypothesized Dimensions of Trust}

Since the way trust is conceptualized varies within and across disciplines, assembling a meaningful list of trust's components presents a challenge. Some fairly comprehensive reviews of trust research literature have been done. For instance, Bigley and Pearce (1998) conducted a review of literature based around different contexts for trusting relationships, while the review done by Mayer and others (1995) looked at trust's antecedents. In the years since these reviews were published, the trust literature base has continued to expand. For this project, 14 contributors to trust were drawn from the literature, particularly those most relevant to public trust in public lands management (Table 1). These contributors do not result in trust by 
Table 1 Previously identified contributors to trust

\begin{tabular}{|c|c|c|}
\hline Dimension & Contributor & References \\
\hline \multirow[t]{6}{*}{$\begin{array}{l}\text { Shared norms and } \\
\text { values }\end{array}$} & Agreement & $\begin{array}{l}\text { Farris and others 1973, Hart and others 1986, Institute for Social Research 1999, Johnson 1999, } \\
\text { Miller 1974, Rosen and Jerdee 1977, Sitkin and Roth } 1993\end{array}$ \\
\hline & Integrity & $\begin{array}{l}\text { Butler 1991, Citrin and Muste 1999, Larzelere and Huston 1980, Lieberman 1981, Peters and others } \\
\text { 1997, Ring and Van de Ven 1992, Sheppard and Sherman } 1998\end{array}$ \\
\hline & $\begin{array}{r}\text { Compassion and } \\
\text { understanding }\end{array}$ & $\begin{array}{l}\text { Citrin and Muste 1999, Johnson 1999, Larzelere and Huston 1980, Mishra 1996, Peters and others } \\
\text { 1997, Ring and Van de Ven 1992, Sheppard and Sherman 1998, Solomon 1960, Strickland } 1958\end{array}$ \\
\hline & Responsiveness & Butler 1991, Citrin and Muste 1999, Jones and others 1975, Mason and others 1985 \\
\hline & Procedural justice & Butler 1991, Citrin and Muste 1999, Levi 1998, Van den Boss and others 1998 \\
\hline & Worthy of pride & Butler 1991, Citrin and Muste 1999, Peters and others 1997 \\
\hline \multirow{3}{*}{$\begin{array}{l}\text { Willingness to } \\
\text { endorse }\end{array}$} & Confidence & Institute for Social Research 1999 \\
\hline & Political inclusion & $\begin{array}{l}\text { Butler 1991, Farris and others 1973, Gabarro 1978, Hart and others 1986, Mason and others 1985, } \\
\text { Mishra 1996, Peters and others } 1997\end{array}$ \\
\hline & Trustworthy & Citrin and Muste 1999, Cook and Wall 1980, Good 1988 \\
\hline \multirow{5}{*}{$\begin{array}{l}\text { Perceived } \\
\text { efficacy }\end{array}$} & Previous experience & Boyle and Bonacich 1970, Fukuyama 1995, Gabarro 1978, Giffin 1967, Kramer 1999 \\
\hline & Competence & $\begin{array}{l}\text { Butler 1991, Cook and Wall 1980, Deutsch 1960, Giffin 1967, Good 1988, Hovland and others 1953, } \\
\text { Johnson 1999, Kee and Knox 1970, Lieberman 1981, Miller 1974, Mishra 1996, Peters and others } \\
\text { 1997, Rosen and Jerdee 1977, Sheppard and Sherman } 1998\end{array}$ \\
\hline & Effectiveness & Butler 1991, Citrin and Muste 1999, Cook and Wall 1980 \\
\hline & Uncertainty & Mason and others 1985, Peters and others 1997 \\
\hline & Reliability & $\begin{array}{l}\text { Butler 1991, Fukuyama 1995, Giffin 1967, Johnson-George and Swap 1982, Mishra 1996, Sheppard } \\
\text { and Sherman } 1998\end{array}$ \\
\hline
\end{tabular}

themselves, but rather, they collectively define a relationship's level of trust. In the most trusting of relationships, all of trust's contributors may be completely represented; as the level of trust in a relationship decreases, the strength and presence of trust's contributors decrease as well. Not all of trust's determinants are necessary to have trust per se, and the exact number required to have trust cannot be known precisely. Depending on the particular context, some contributors may play a more crucial role than others. However, each of the contributors has the potential to influence overall perceptions of trust.

The 14 contributors to trust have similarities to one another that allow them to be grouped together into dimensions. Understanding trust's dimensions helps shed light on its complex nature and clarifies the strengths and weaknesses of trusting relationships. There are three facets of trust that we suggest reflect the major dimensions of trust. First, it is hypothesized that trust is built on a foundation of Shared Norms and Values, providing a basis for people and organizations to trust one another. Second, people and organizations will likely trust one another only to the extent to which they can know the other parties are acting appropriately on their behalf (Willingness to Endorse), that they can know of the behavior of those others to be worthy of trust, and that they have confidence in the potential outcome or range of outcomes. Third, based on what parties believe others to be capable of (Perceived
Efficacy), they will extend an appropriate degree of trust. These three dimensions, with their contributing attributes, are hypothesized to collectively determine the level of trust in a particular relationship or situation. Each of these three dimensions contains a number of elements that further help describe it.

\section{Shared Norms and Values}

Trust is built on a notion of values common throughout a social community. These values are a common thread that ties parties together based on moral similarity. Fukuyama (1995) defines trust as "the expectation that arises within a community of regular, honest, and cooperative behavior, based on Commonly Shared Norms, on the part of other members of that community" (p. 26; emphasis added). The extent to which parties that have shared norms and values are able to place common goals above individual goals is mediated by the extent to which its members can relate to one another. While establishing formal contracts and behaving within one's self interest are important ways of relating cautiously to others (and thereby reducing risk), a shared moral standard provides a basis for mutual trust, lessening the need for extensive contractual and legal regulation (Fukuyama 1995). With a shared moral platform, parties are able to operate outside the arena of formal rules and regulation, being confident that others will not act 
maliciously. This provides escape from regulatory oversight, accounting, and control, and leads to greater flexibility, responsiveness, and efficiency of action. To benefit from these efficiencies, parties may tend to invest a number of resources into building and strengthening trusting relationships (Levi 1998).

Six contributors have been found to define Shared Norms and Values. The first is Integrity: public lands managers and agencies that are perceived to behave with honesty, morality, good character, and honor in their actions are more likely to be trusted. That is, these specific virtues are valued similarly by the public and by managers and agencies. The extent to which others are believed to be Worthy of Pride has also been found to contribute to Shared Norms and Values. Resource managers and agencies that conduct themselves in a manner that is respectful, is discrete, and has high levels of commitment are more likely to gain the trust of the public. Compassion and Understanding also contributes to Shared Norms and Values and refers to managers and agencies that are sympathetic, caring, and concerned with the welfare of others, as exemplified by their benevolent actions and goodwill toward others. Especially in situations where people's lives or property is vulnerable such as forest fires, behaving with compassion and understanding can be crucial, as it shows care and concern for others' well-being. Agreement, or congruence of values, is also necessary and refers to the parallel objectives the public shares with management agencies. It implies that the cooperating parties are oriented in corresponding directions and satisfied with that shared goal. Procedural Justice contributes to Shared Norms and Values and refers to the fairness and equity of the processes used to make and implement decisions. Procedural Justice implies that agency relations with different people or organizations are consistent, just, and impartial. Finally, Responsiveness refers to a party's receptiveness and ability to pay attention to and adapt to changing needs and circumstances. As situations change, parties must be available and able to change along with them, attentive to everyone's needs and interests.

\section{Willingness to Endorse}

Another facet important in trusting others is that parties will voluntarily trust others if they believe that the others are worthy of being trusted. As Mayer and others (1995, p. 712) state, "Ttrust is not taking a risk per se, but rather it is a willingness to take risk" (emphasis added). Trust's voluntary nature is important, because it suggests that if certain conscious or unconscious criteria are not met, trust will not be extended. When people have confidence in a range of potential actions or outcomes, know they have a political voice, and know that others are behaving in a manner deserving of trust, they are more willing to endorse the actions of others with their trust.

In the Willingness to Endorse dimension, three hypothesized contributors to trust have been described. Trustworthy Behavior refers to managers and agencies that conduct themselves in a manner that warrants the trust of others and implies that people have a reason to trust them and their claims about how they intend to behave, rather than relying on blind faith. Political Inclusion is the second contributor and indicates the degree to which people have a say or a role in relevant decision-making processes. This means that agencies are open to, and receptive to, hearing the needs of people or other organizations. It does not necessarily imply that their needs and desires are fulfilled - only that those wishes are received and recognized. When people feel they are included and heard, they are more willing to have faith in the decision-makers to consider and take their concerns into consideration. Confidence is the last contributor to the dimension and refers to parties' ability to act with faith, certainty, or assurance, because they "know" that a certain outcome or range of outcomes can be expected. The more confident a person is in another, the more likely he or she is to endorse that other individual to act on his or her behalf.

\section{Perceived Efficacy}

The third aspect important to trusting others revolves around what people believe they know about others' capacity or ability to act-their Perceived Efficacy. This perception influences parties' expectations (Blackburn 1998), and since trust is inherently dependent on the expectation of others (Fukuyama 1995), the perceived efficacy of others is important. Based in part on parties' perceptions of what others are able to do, parties extend varying degrees of trust. The more it seems people or organizations are capable of in a set of circumstances, the more trust will likely be extended. Conversely, the less it seems others are capable of in given circumstances, the less trust will likely be extended.

In the Perceived Efficacy dimension, five defining contributors are suggested. Competence, the first contributor, refers to the ability of agencies to effectively implement their skills, knowledge, or expertise in a given arena. It implies that they have the wherewithal to get something done right the first time. The public trusts that the time and effort spent working with the agency will be reflected in the ability of those they interact with. Reliability is the extent to which a party can be counted on to perform a given function, or behave in a certain predictable and consistent manner. Previous Experience refers to earlier interactions members of the public have had with others that color their attitudes of consistency and familiarity. It can be based on 
interactions that people or organizations have had or on a reputation from past interactions in similar circumstances. Over a series of interactions, people are able to learn more about the skills, knowledge, and ability of others to act. That is, the greater the previous experience of working with an agency, the greater the opportunity to build, or lose, trust in that agency. Effectiveness refers to managers' ability to successfully accomplish goals and have a desired effect on what was intended, to live up to promises made, and to maintain good credibility. Uncertainty is the last contributor to the efficacy dimension and refers to the grades of knowability or unknowability associated with engaging in a relationship with certain parties or performing certain actions. The greater the uncertainty involved in a relationship, the more hesitant people may be to trust and the less willing they might be to take the risk to trust.

Analytically, this paper seeks to examine the causal structure of trust by examining two models: the threedimensional model of trust described above and a onedimensional model in which each of the 14 contributors influences trust directly. These causal relationships are examined using structural equation modeling (SEM; Kline 2005). SEM provides a means of exploring the relationship between one or more independent variables and one or more dependent variables, any of which can be either continuous or discrete. The methodology combines multiple regression with exploratory factor analysis and allows for the analysis of variables that cannot be directly observed and must be measured indirectly through proxy variables, called latent variables. SEM can be described as the pursuit of the best representation of the data collected. In this study, we were particularly seeking to understand how the contributors were related to trust, either within or without the three overlaying dimensions.

\section{Methods}

The present study examines public trust in the context of federal lands fire and fuels management. Fire and fuels management was an appropriate lens through which to view trust for a number of reasons. First, a number of recent major wildfires have brought fire and fuels management into the public's consciousness. In part, many people are moving farther away from urban centers and into the wildland-urban interface, putting more people and property in the path of forest fires. Consequently, they are more likely to be directly impacted by the decisions of public land managers. Second, there has been an increase in educational and economic resources available to landowners living in the wildland-urban inferface to lower their homes' vulnerability to forest fires. Experimental studies and modeling have suggested specific tactics for homeowners to mitigate the threat of wildland fires (Cohen 2000; Barkeley and others 2004). Third, and perhaps most importantly, while all forms of public lands management have ecological, economic, and social implications, fire is potentially more contentious because of its ability to affect people's lives and livelihoods in ways that other forms of public lands management rarely do.

The Bitterroot Valley in western Montana provides the setting for the present study (Fig. 1). The Bitterroot Valley's land base is primarily public; the BNF, Lee Metcalf National Wildlife Refuge, and state land occupy nearly three-fourths of the county (Bitterroot Valley Chamber of Commerce 2005), with the BNF occupying the vast majority of that area. The valley has had numerous recent wildfires and has a high proportion of residents living in the wildland-urban interface. As a result, the area has a variety of fire management needs, ranging from full suppression near developed town centers to wildland fire use in the Selway-Bitterroot Wilderness. A postfire social assessment following the valley's fires of 2000 suggested that some residents had a lack of trust in the BNF to make fire management decisions that reflect local meanings attached to the landscape (Bureau of Business and Economic Research 2001).

For this study, the sample population was defined as all households with a working telephone in Ravalli County, Montana, including the towns of Stevensville, Hamilton, Victor, Darby, Sula, and Alta. U.S. Census data from 2000 indicate that there are approximately 14,289 households in the county. Based on responses from an earlier postfire social assessment (Bureau of Business and Economic Research 2001), and an acknowledgment of the variation in community composition and past experience with fire and

\section{Vicinity Map}

\section{Bitterroot National Forest}

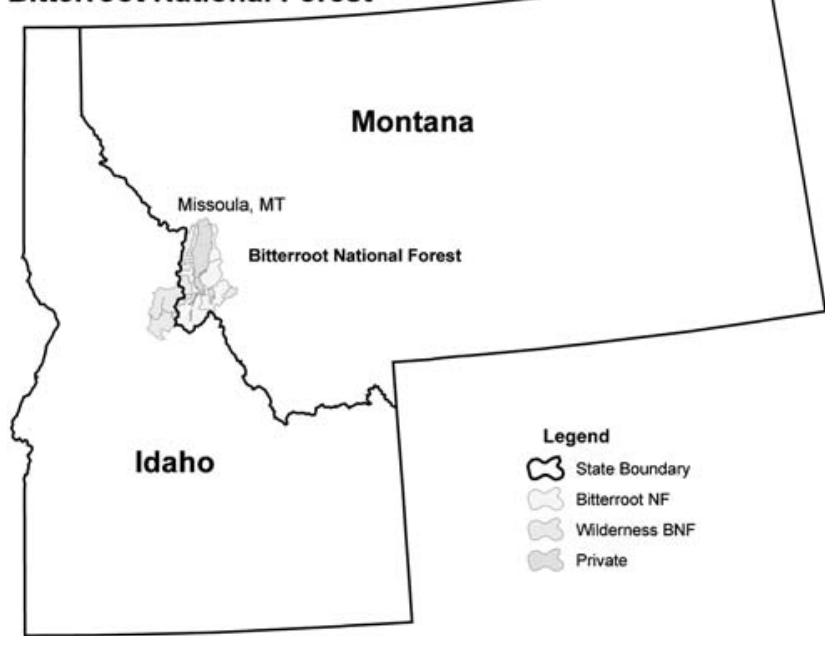

Fig. 1 Vicinity map, Bitterroot National Forest 
fuels management, it was thought that the public's trust may vary across portions of the county. Therefore, the sample was stratified geographically to represent different portions of the county (North, Central, and South) and allow for independent analysis of each portion. Subsequent analysis did, indeed, find significant geographic differences in levels of trust (Liljeblad and others 2005). Samples taken from the three regions of the valley were weighted proportionally to population levels for county-level statistics.

A telephone survey of households in the sample area was administered by The University of Montana's Bureau of Business and Economic Research using a random-digit dial process (Kish 1949) during May and June of 2004. Previous application of this method in a multistate project yielded a 52\% response rate (Borrie and others 2002), though application of this method in the Bitterroot Valley postfire social assessment had previously yielded an $87 \%$ response rate (Bureau of Business and Economic Research 2001). Community members have shown sincere interest in fire and fuels management and high levels of cooperation were anticipated. This contrasts with other telephone surveys, which have experienced significant reductions in response rate over the last several years (Curtin and others 2005; Dillman 2007).

\section{Survey Development}

Survey items for each dimension's contributors were identified in the literature review and modified to fit the fire and fuels management context of this study. When survey items for an attribute could not be identified from the trust literature, questions were created, following established methodological guidelines (Citrin and Muste 1999). The trust items were included as part of a larger survey measuring respondents' experience with, and attitudes toward, forest fires. Trust survey items, and the range of response categories, are presented in the Appendix (Table A1). It should be noted that, given logistic limitations of our survey, only one item is used to measure each of the 14 contributors.

Cognitive interviews utilizing concurrent thinkalouds and concurrent probes were conducted with four residents of the study area to investigate respondents' thought processes when answering the survey and to explore potential problems with survey questions (Sudman and others 1995). Changes clarifying survey items were made after cognitive interviews suggested that there were potential minor problems with question wording. After this refinement, a pilot test was given to 100 households in a community immediately outside the study area, examining question wording, order, and technical implementation of the survey. Results of the pilot test suggested that question order influenced results. Thus, other survey items (asking about the respondent's general level of cynicism) were reordered to later in the questionnaire to have the least influence on the trust items. These survey items were not included in current analyses.

\section{Structural Equation Modeling}

SEM typically involves a number of analytical steps. First, a theoretical model is developed from previous research and literature. This determines which variables will be included in the model and how these variables are related. In this paper, our interest was in the 14 contributors to trust, the three overlying dimensions, and their relationship to one another. We specified one model with the three dimensions and one without. SEM then estimates the population parameters, which includes the use of a number of estimation methods (ordinary least squares, maximum likelihood, etc.). In our case, given the discrete nature of a number of the variables (i.e., ordinal, categorical), a generalized least squares (GLS) method is recommended (Schumaker and Lomax 2004).

In testing whether the data fit the models a number of criteria are calculated based on a chi-square statistical test of significance (we use AGLS, the Arbitrary Generalized Least Squares Fit Index). There is no single fit index to statistically identify the correct model; rather, collectively they confirm plausible and acceptable models. Then a number of fit indexes (we use SRMR, Standardized Root Mean-Square Residual; and CFI, Comparative Fit Index) can be used to compare the fit of different models given the same data. A general goal of a parsimonious model encourages fewer specified paths or relationships between variables (Schumaker and Lomax 2004). We use Akaike's Information Criterion (AIC) to measure this, with lower, positive AIC values indicating more parsimony.

The second test of statistical significance for a potential model is on the individual parameter estimates in the model, also known as path coefficients. Standardized path coefficients (with equal variance) indicate effect size, much as beta weights do in regression analyses. Coefficients range from 0 , indicating little or no substantive input, and increase in importance in the causal relationship to a maximum value of 1.0. The standardized coefficients, however, are specific to the sample and not comparable across samples (Hair and others 1998).

\section{Results}

Telephone interviewers contacted 1,690 qualified respondents. Including those that rescheduled appointments with interviewers multiple times but never completed a survey, slightly more than one-fourth of all attempted calls were considered refusals. In addition, about $5 \%$ of all households contacted were considered "valid, but noninterviewable," 
because respondents were incapable of completing the survey during the sampling period due to illness, previously scheduled vacations, or other factors uncontrollable by interviewers. Excluding these, 1,164 surveys were completed, taking an average of 15-20 min. Twelve completed surveys were lost to a corrupted data file, yielding 1,152 usable surveys and a final response rate of $68 \%$.

The sample was almost evenly split across gender, with $48.6 \%$ male and $51.4 \%$ female, closely matching proportions identified in the 2000 U.S. Census for Ravalli County (49.7\% and $50.2 \%$, respectively). The age of respondents ranged from 18 to 91 years, with a mean of 51.6 years $(\mathrm{SD}=16.8$ years). Respondents had lived in Ravalli County on average for 19.2 years $(\mathrm{SD}=16.5$ years), ranging from a minimum of $<$ year to a maximum of 91 years. Nearly $95 \%$ of respondents had at least a highschool diploma or GED, with more than a quarter having graduated from college and $<10 \%$ possessing a graduate degree. In the sample, nearly two-thirds of households have an annual income of between $\$ 20,000$ and $\$ 75,000$. Data from the 2000 U.S. Census closely mirror this distribution, though higher incomes were slightly oversampled. Nearly $90 \%$ of respondents claim to have been somewhat affected or very affected by smoke and previous fires in the Bitterroot Valley.

Responses to the 14 trust survey items are listed in Table 2. Looking at the contributors to Shared Norms and Values, respondents generally think the BNF acts with integrity, compassion, and responsiveness to local needs when fighting fires. Almost all respondents are proud of the way fire is managed in the BNF, although generally speaking they are not completely satisfied with the process used to do so. The responses to items measuring Willingness to Endorse indicate that while the BNF staff are considered trustworthy, those managers are, on average, not perceived to be paying a good deal of attention to what people think, and have only low levels of confidence from residents. In general, respondents have middle-range views on the efficacy and ability of BNF fire managers to follow through on their objectives. They think, on average, that the BNF managers are only somewhat effective, reliable, and competent in managing forest fires. Residents have quite varied levels of certainty and approval of the way fires in the BNF are managed.

\section{Structural Equation Modeling}

A GLS hierarchical structural equation model with arbitrary GLS (AGLS) nonnormal estimation correction was conducted on the correlation structure of trust items using the SEM program EQS 6.1 (Bentler and $\mathrm{Hu}$ 2005). An initial model, called Model A (Fig. 2), was created, with
Table 2 Mean trust contributor scores

\begin{tabular}{llll}
\hline Dimension & Contributor & Mean $^{\mathrm{a}}$ & SD \\
\hline Shared norms and values & Agreement & 2.66 & 0.98 \\
& Integrity & 2.88 & 0.65 \\
& Compassion and & 3.35 & 0.80 \\
& understanding & & \\
& Responsiveness & 3.21 & 0.82 \\
& Procedural justice & 2.73 & 0.69 \\
& Worthy of pride & 0.90 & 0.46 \\
Willingness to endorse & Confidence & 2.66 & 0.81 \\
& Political inclusion & 1.93 & 0.68 \\
& Trustworthy & 3.13 & 0.85 \\
Perceived efficacy & Previous experience & 2.66 & 0.98 \\
& Competence & 2.65 & 0.74 \\
& Effectiveness & 2.58 & 0.85 \\
& Uncertainty & 2.75 & 0.99 \\
& Reliability & 2.92 & 0.83 \\
\hline
\end{tabular}

Note: Full text of survey questions and response categories are listed in the Appendix

${ }^{\text {a }}$ Response formats vary but generally range from 1 to 4 (Worthy of Pride ranges from 0 to 1 ; Political Inclusion ranges from 1 to 3 )

the three dimensions of trust and trust itself as latent variables and each survey item as an observed variable.

AIC for Model A was 90.584, the CFI was 0.977, and the SRMR was 0.101. These results fall just beyond $\mathrm{Hu}$ and Bentler's (1999) paired fit guidelines of CFI $<0.96$ and SRMR $>0.10$. The AGLS Fit Index was 0.990, suggesting that the model had a near-perfect fit, according to the guidelines recommended by Kline (2005). Table 3 reports the fit statistics for all three indexes, as well as recommended fit guidelines. All trust contributors had standardized path coefficients of close to or $>0.80$, with the exception of the variables "worthy of pride" and "uncertainty," which had values of 0.677 and 0.681 , respectively (see Table 4). In broad terms, these results confirm the three dimensions of trust in the data collected for this study. They also confirm the relevance of each of the 14 contributors within those three dimensions.

The second model, Model B, was calculated using the same methodology as above to compare the three-dimensional representation of trust to a one-dimensional representation as shown in Fig. 3. AIC for the onedimensional model of trust was 92.026, the CFI was 0.976, and the SRMR was 0.106. These results fall just below $\mathrm{Hu}$ and Bentler's (1999) paired fit guidelines of CFI $<0.96$ and SRMR $>0.10$. The AGLS was 0.990, the same as for Model A. Like Model A, all observed variables had standardized path coefficients of close to or $>0.80$, with the exception of the same two variables, "worthy of pride" (0.678) and "uncertainty" (0.679). Standardized path 
Fig. 2 Initial structural equation model (Model A): influence of shared values, willingess to endorse, and perceived management efficacy on levels of trust in public lands managers

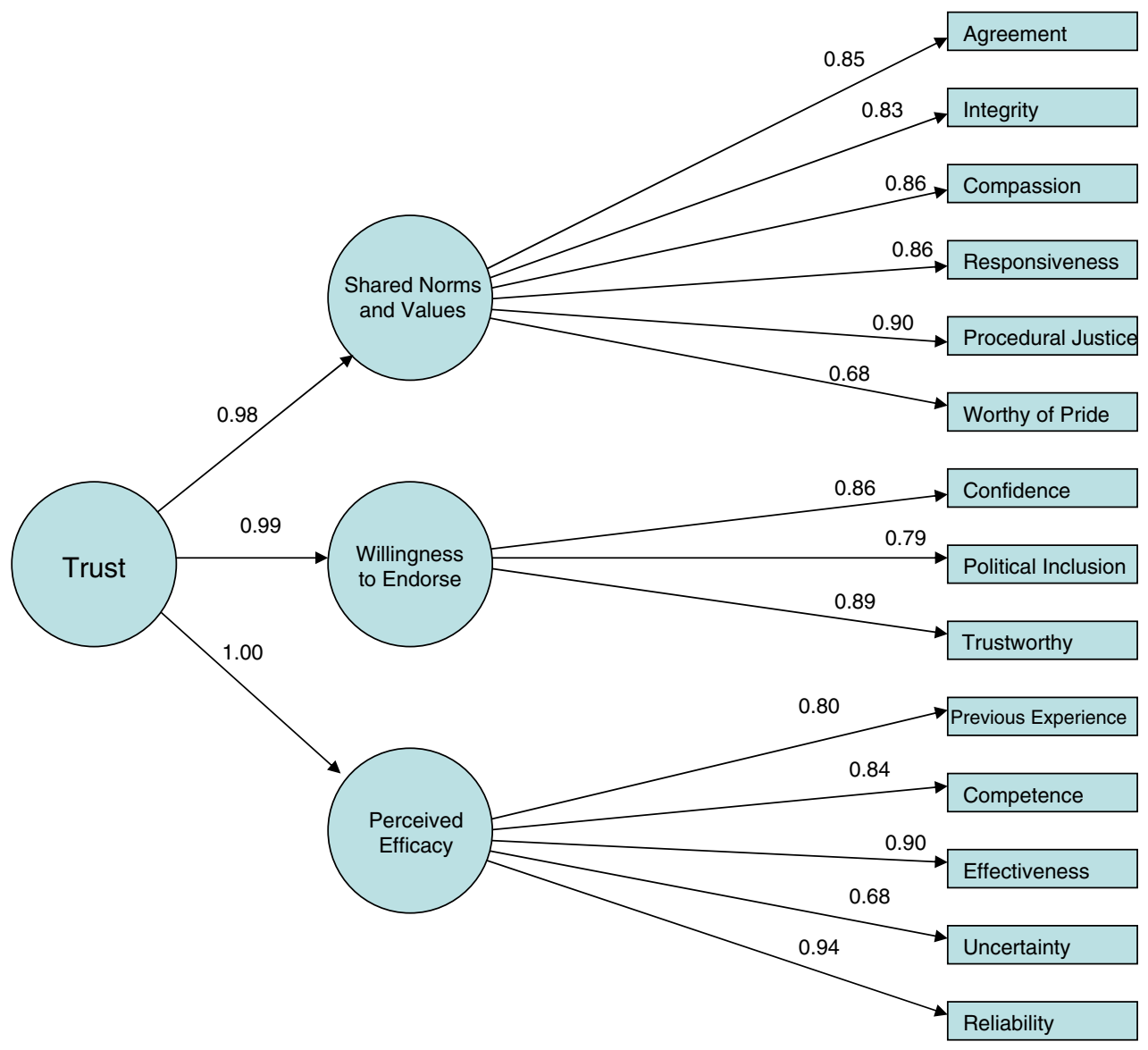

Table 3 Fit indexes for structural equation models of trust

\begin{tabular}{lccl}
\hline Fit index & Model A & Model B & Paired-fit guideline $^{\mathrm{a}}$ \\
\hline CFI & 0.977 & 0.976 & $>0.96$ \\
SRMR & 0.101 & 0.106 & $<0.10$ \\
AGLSFI & 0.990 & 0.990 & \\
AIC & 90.584 & 92.026 & \\
\hline
\end{tabular}

Note: CFI, Comparative Fit Index; SRMR, Standardized Root MeanSquare Residual; AGLSFI, Arbitrary Generalized Least Squares Fit Index; AIC, Akaike's Information Criterion

${ }^{a}$ From Hu and Bentler (1999)

coefficients for both models are listed in Table 4, indicating that all determinants were important to trust (although it is likely that the specific values for each determinant and the importance of each relative to the others are unique to the specific context in which their data were collected).

While an empirical distinction between the fit of the two models can be noted, the real-world distinction is less clear. Since AIC of Models A and B are within close proximity to one another, it raises the question of how different the two models really are. Unnecessarily dimensionalizing trust suggests that the dimensions themselves may be nominal, with less empirical relevance. We might suggest, however, that the dimensions are useful practically as a framework for conceptualizing trust and useful as categories for grouping. In summary, these results do show the empirical relevance of the 14 identified contributors to trust and the appropriateness of grouping them into three conceptual dimensions.

\section{Discussion}

Many studies of trust in public lands management do not contribute as much as might be possible to understanding why a managing agency is or is not trusted to perform a given action (e.g., Cvetkovich and Winter 2003; Winter and others 2004). Studies such as these provide useful information about the public's level of trust and have begun to look into why or in what ways an agency is or is not trusted. Not only can an in-depth approach, such as examined in this study, reveal the extent to which resourcemanaging agencies are or are not trusted, but also it provides insight into what managers are doing right and what they need to work on in terms of their relationship with the public. This detailed portrait of trust provides a more informative and more accurate measure of trust, which is likely to be more useful to resource managers than simply knowing whether or not they are trusted. Previous authors have considered specific factors that influence trust (e.g., 
Table 4 Standardized path coefficients, error, and $R^{2}$ values for structural equation models of trust

\begin{tabular}{|c|c|c|c|c|c|c|c|}
\hline \multirow[t]{2}{*}{ Variable } & & \multicolumn{3}{|l|}{ Model A } & \multicolumn{3}{|l|}{ Model B } \\
\hline & & $\begin{array}{l}\text { Standardized path } \\
\text { coefficient }\end{array}$ & Error & $R^{2}$ & $\begin{array}{l}\text { Standardized } \\
\text { path coefficient }\end{array}$ & Error & $R^{2}$ \\
\hline \multicolumn{8}{|l|}{ Attribute } \\
\hline V1 & Agreement & 0.858 & 0.514 & 0.736 & 0.854 & 0.521 & 0.729 \\
\hline $\mathrm{V} 2$ & Integrity & 0.830 & 0.558 & 0.689 & 0.826 & 0.564 & 0.682 \\
\hline V3 & Compassion and Understanding & 0.865 & 0.502 & 0.748 & 0.864 & 0.503 & 0.747 \\
\hline V4 & Responsiveness & 0.856 & 0.516 & 0.733 & 0.857 & 0.515 & 0.735 \\
\hline V5 & Procedural justice & 0.900 & 0.437 & 0.809 & 0.897 & 0.442 & 0.804 \\
\hline V6 & Worthy of pride & 0.677 & 0.736 & 0.459 & 0.678 & 0.735 & 0.460 \\
\hline V7 & Confidence & 0.865 & 0.502 & 0.748 & 0.862 & 0.507 & 0.743 \\
\hline V8 & Political inclusion & 0.786 & 0.618 & 0.618 & 0.781 & 0.625 & 0.610 \\
\hline V9 & Trustworthy & 0.888 & 0.459 & 0.789 & 0.878 & 0.478 & 0.771 \\
\hline V10 & Previous experience & 0.799 & 0.601 & 0.639 & 0.798 & 0.603 & 0.636 \\
\hline V11 & Competence & 0.843 & 0.538 & 0.710 & 0.845 & 0.535 & 0.714 \\
\hline V12 & Effectiveness & 0.896 & 0.444 & 0.803 & 0.897 & 0.443 & 0.804 \\
\hline V13 & Uncertainty & 0.681 & 0.733 & 0.463 & 0.679 & 0.735 & 0.461 \\
\hline V14 & Reliability & 0.935 & 0.354 & 0.875 & 0.933 & 0.359 & 0.871 \\
\hline \multicolumn{8}{|c|}{ Dimension } \\
\hline $\mathrm{F} 1$ & Shared norms and values & 0.982 & 0.187 & 0.965 & - & - & - \\
\hline $\mathrm{F} 2$ & Willingness to endorse & 0.989 & 0.147 & 0.978 & - & - & - \\
\hline $\mathrm{F} 3$ & Efficacy & 1.000 & 0.000 & 1.000 & - & - & - \\
\hline
\end{tabular}

Winter and others 2004), but there still exists a need to better document the internal dynamics of trust. We believe that a more detailed measurement of trust as a dependent variable was needed. Trust can then serve as a basis for benchmarking public processes, allowing monitoring of responsiveness to the expectations of the public.

\section{Building Trust}

All employees of public land management agencies influence the public's perceptions of that agency, through their direct or indirect actions. Through those public perceptions, of course, the public grants or reserves their trust. By exemplifying the attributes of trust identified in this article, every action by an agency employee could potentially help increase or maintain the public's trust in the agency. It is especially important for those managers who frequently interact with the public to ensure that their actions are not detrimental to trust.

Focusing on the relationship between individual agency representatives and the public, however, should not be the only way that issues of trust are addressed by managing agencies. It is necessary that organizations pay attention to all the internal and external relationships they are involved in (Morgan and Hunt 1994). While agencies are generally mandated to manage the land on behalf of the public, some agencies, especially U.S. federal agencies, have responsibilities beyond that. These managers have a public purpose mandate to consider the ecological, economic, and social values of an area in all their management decisions and ensure that they fulfill their obligations as stewards (Borrie and others 2002).

Trust, and its components, can be used as an indicator of achievement of the public purpose of public lands. Managers might use it as a scorecard of sorts, with specific criteria within performance reviews. This would be in contrast to current measures, which too often assess the number of current lawsuits an agency is involved in or the proportion of public comments in opposition to proposed actions. While these informal measures provide important information about how well agencies are doing, they do not provide sufficient detail. By conducting formal, in-depth measures of trust, managers can empirically assess how well they are doing. By monitoring trust levels over time, managing agencies will have a better idea of how well they are doing as managers and public servants in stewarding the relationship between the public and public lands. Given the relative nature of the measurement of the components of trust, changes in those scores over time indicate which components are improving or declining. Managers are thus able to target specific behaviors underlying public perceptions of trust.

By concerning themselves with the public's level of trust in their management, agencies help strengthen the 
Fig. 3 Alternative structural equation model (Model B): influence of 14 contributors on levels of trust in public lands managers

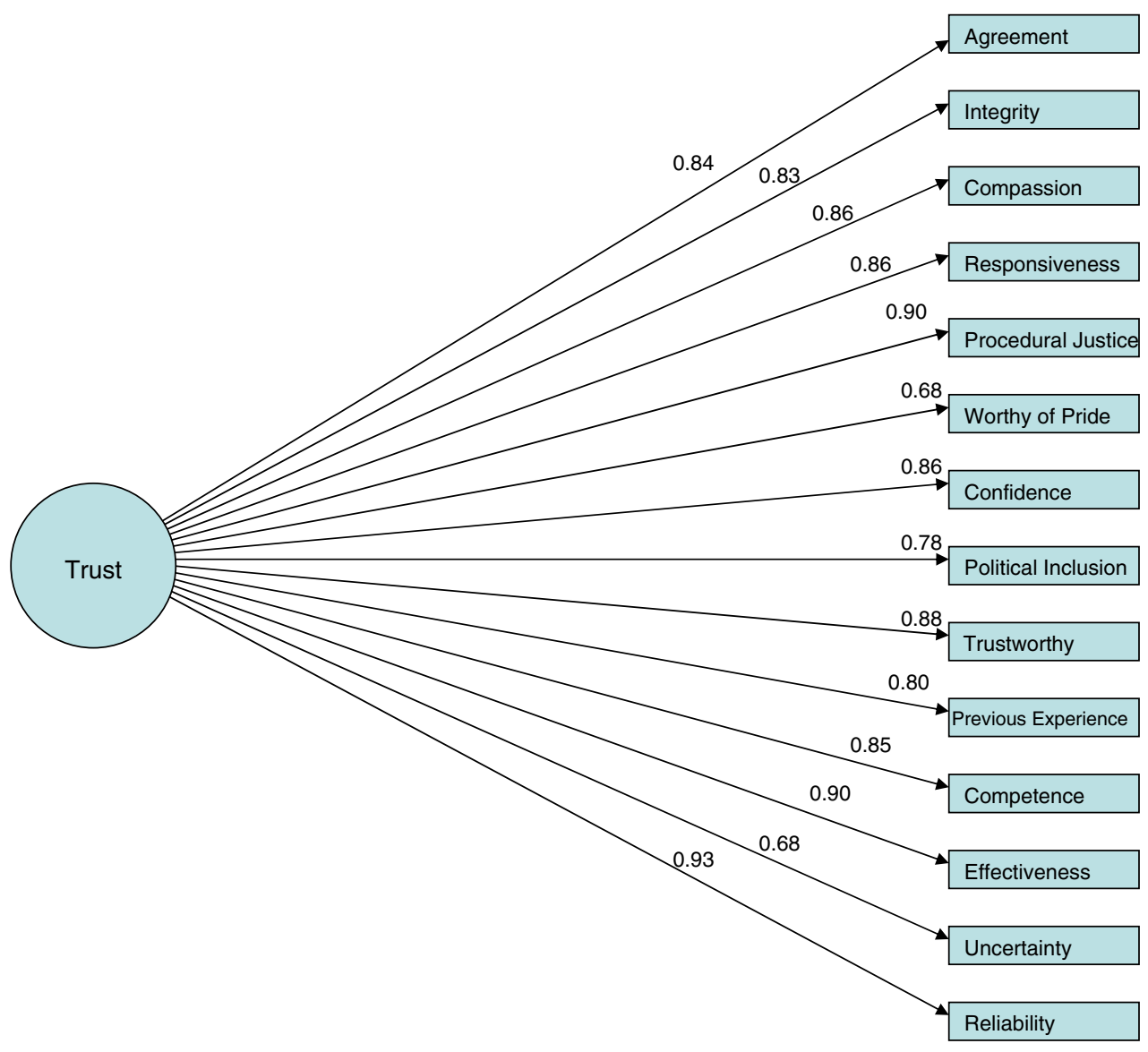

relationship the public has with the land, likely leading to increased cooperation between divergent parties, decreased opposition to management actions, and fewer lawsuits. When public lands management agencies pay attention to how their actions affect the public's relationship with the land, managers are better able to truly be public stewards and, in doing so, confidently make decisions. In doing so, they engender higher levels of trust from the public, which, again, improves their ability to accomplish the purpose of public lands. Knowing how to improve a relationship with the public through attention to the various contributors to trust not only strengthens the ability to manage but also strengthens that relationship with the public.

\section{Researching Trust}

The results of this study are most applicable to those interested in the future study of trust in public lands management and, specifically, in trust in the management of forest fires and fuels. More holistic models of trust must be used to guide future studies of trust. The confirmation of the three-dimensional, multiattribute model of trust by the data gathered from public input in this Montana community suggests that we need to study this complex phenomenon using appropriately complex models and analysis. Obviously while this is possible in research and will give us greater understanding of how trust is built and maintained, complex approaches often restrict application potential. While we now have confidence in the range of important contributors to overall trust measures, and subsequent investigations are expected in different communities and contexts, scientists might now focus on condensing these models to a manageable set of proxy items to be used in measuring and monitoring trust within specific communities or associated with specific management actions. That is, quite complex analyses, such as Classification and Regression Tree (CART) methods (Berk 2006), could identify indicators that fully represent the threedimensional, multiattribute model of trust.

Scientists could also create greater potential for application of trust research to the accomplishment of resource management objectives by further studying the role of individual employees in influencing levels of trust in public lands management agencies and also the role of trust within an agency. With many public lands management agency employees frequently changing employment locations, the increasing use of outside fire management teams to make local tactical decisions, and the perception that local decisions are often driven by national policy or activist group opinions, many interpersonal interactions could have an influence on overall trust in agency actions. These outcomes 
are frequently a result of both regional and national policy decisions and need to be explored more. Trust in a natural resource management agency is measurable at levels from trust in the most local aspects (individual managers and specific processes) to trust in the government in general. Their interactions are currently poorly understood and researchers lack guidance as to how to measure trust given these different levels of operationalization.

Within an agency, there is very little research on or understanding of how perceived liability and risk (see, e.g., Aplet 2006) and commitment to, or understanding of, agency resource management objectives can contribute to or constrain building trust and commitment among public lands management agency employees. Just as public trust is important to accomplishing these objectives, there is potential for internal agency trust, intergenerational or political differences in beliefs about public lands purposes, and hierarchical differences in perceptions of how liability is associated with decision-making to influence ability to achieve resource benefit objectives.

Finally, with the increased emphasis on agency commitments to managing high-risk fire situations with mindfulness (Weick and Sutcliffe 2001), there is a need to understand whether following these highly advocated principles that commonly guide high-reliability organizations are accurately perceived by the public and would also contribute to public trust in fire and fuels management. Knotek and Watson (2006) have suggested that public involvement in fuel management decisions can be accomplished in a way that incorporates these mindfulness principles and can, in fact, serve to increase public perceptions of responsiveness to public interests and proper stewardship of relationships the public has with public lands.

Acknowledgments This project was funded in part by the Joint Fire Science Program, the Bitterroot Ecosystem Management Research Project, the USDA Forest Service Rocky Mountain Research Station, and The University of Montana. The authors would like to sincerely thank those organizations, the Bitterroot National Forest, and Jim Sylvester and John Baldridge at The University of Montana Bureau of Business and Economic Research.

\section{Appendix}

Table A1 Text and response formats of survey questions

\begin{tabular}{lc}
\hline Agreement: Generally speaking how satisfied are you, if at all, with \\
the way the Bitterroot National Forest staff deals with fires? \\
Very satisfied & 4 \\
Somewhat satisfied & 3 \\
Somewhat dissatisfied & 2 \\
Very dissatisfied & 1 \\
Don't know & - \\
\hline
\end{tabular}

Table A1 Appendix continued

Integrity: When managers of the Bitterroot National Forest speak on television, radio, in newspapers, or at public meetings about forest fires, how often, if at all, do they tell the truth?

$\begin{array}{ll}\text { Always } & 4 \\ \text { Mostly } & 3 \\ \text { Less than half of the time } & 2 \\ \text { Never } & 1 \\ \text { Don't know } & -\end{array}$

Compassion and Understanding: I believe the Bitterroot National Forest staff demonstrates a general attitude of compassion when fighting fires.

$\begin{array}{ll}\text { Strongly agree } & 4 \\ \text { Somewhat agree } & 3 \\ \text { Somewhat disagree } & 2 \\ \text { Strongly disagree } & 1 \\ \text { Don't know } & -\end{array}$

Responsiveness: Managers of the Bitterroot National Forest respond to the needs of local residents when fighting fires.

$\begin{array}{ll}\text { Strongly agree } & 4 \\ \text { Somewhat agree } & 3 \\ \text { Somewhat disagree } & 2 \\ \text { Strongly disagree } & 1 \\ \text { Don't know } & -\end{array}$

Procedural Justice: How often, if at all, do you think fires in the Bitterroot National Forest are managed according to a fair process?

$\begin{array}{ll}\text { Always } & 4 \\ \text { Mostly } & 3 \\ \text { Less than half of the time } & 2 \\ \text { Never } & 1 \\ \text { Don't know } & -\end{array}$

Worthy of Pride: Would you say that you are proud of the way fire is managed in the Bitterroot National Forest, or that you can't find too many things about the fire management to be proud of?

Proud of fire management $\quad 1$

Can't find much 0

Don't know -

Confidence: How much, if any, confidence do you have in fire managers in the Bitterroot National Forest? Do you have:

$\begin{array}{ll}\text { Complete confidence } & 4 \\ \text { Quite a lot of confidence } & 3 \\ \text { Not very much confidence } & 2 \\ \text { No confidence at all } & 1 \\ \text { Don't know } & -\end{array}$

Political Inclusion: How much attention, if any, have Bitterroot National Forest managers paid to what people think when managers decide what to do about forest fires?

$\begin{array}{ll}\text { A good deal of attention } & 3 \\ \text { Some attention } & 2 \\ \text { Not much attention } & 1 \\ \text { Don't know } & -\end{array}$


Table A1 continued

Trustworthy: Residents of the Bitterroot Valley say that the Bitterroot National Forest staff is trustworthy when fighting fires.

$\begin{array}{ll}\text { Strongly agree } & 4 \\ \text { Somewhat agree } & 3 \\ \text { Somewhat disagree } & 2 \\ \text { Strongly disagree } & 1 \\ \text { Don't know } & -\end{array}$

Previous Experience: In the past how pleased, if at all, have you been with the way fires in the Bitterroot National Forest were managed?

Very pleased 4

Somewhat pleased

3

Somewhat displeased

Very displeased

2

Don't know

1

$-$

Competence: Based on your observations and experiences, what portion, if any, of the people who manage forest fires in the Bitterroot National Forest know what they are doing?

$\begin{array}{ll}\text { All } & 4 \\ \text { Most } & 3 \\ \text { Less than half } & 2 \\ \text { None } & 1 \\ \text { Don't know } & -\end{array}$

Effectiveness: In your community, how would you rate the effectiveness of Bitterroot National Forest fire managers in dealing with fire-related issues?

$\begin{array}{ll}\text { Excellent } & 4 \\ \text { Good } & 3 \\ \text { Fair } & 2 \\ \text { Poor } & 1 \\ \text { Don't know } & -\end{array}$

Uncertainty: How sure, if at all, have you felt that forest fires threatening your community or your property would be put out in time?

Very sure 4

Somewhat sure 3

Somewhat unsure 2

Very unsure 1

Don't know

Reliability: I find the Bitterroot National Forest staff to be reliable when managing fires.

Strongly agree 4

Somewhat agree 3

Somewhat disagree 2

Strongly disagree 1

Don't know

\section{References}

Aplet GH (2006) Evolution of wilderness fire policy. International Journal of Wilderness 12(1):9-13
Barkeley YC, Schnepf C, Cohen JD (2004) Protecting and landscaping homes in the wildland/urban interface. Station Bulletin 67: January 2005. Idaho Forest, Wildlife and Range Experiment Station, University of Idaho Extension, Moscow

Bentler PM, Hu EJC (2005) EQS 6.1 for Windows user's guide. Multivariate Software, Inc., Encino, CA

Berk RA (2006) An introduction to ensemble methods for data analysis. Sociological Methods and Research 34(3):263-295

Bigley GA, Pearce JL (1998) Straining for shared meanings in organization science: problems of trust and distrust. Academy of Management Review 23:405-421

Bitterroot Valley Chamber of Commerce (2005) Available at: http://www.bvchamber.com/local_info/government.php

Blackburn S (1998) Trust, cooperation, and human psychology. In: Braithwaite V, Levi M (eds) Trust and governance. Russell Sage Foundation, New York, pp 28-45

Borrie WT, Christensen N, Watson AE, Miller TA, McCollum DW (2002) Public purpose marketing: a focus on the relationships between the public and public lands. Journal of Park and Recreation Administration 2:49-68

Boyle R, Bonacich P (1970) The development of trust and mistrust in mixed-motive games. Sociometry 33:123-139

Bureau of Business and Economic Research (2001) Bitterroot National Forest social survey. Unpublished report. University of Montana, Missoula

Butler JK (1991) Toward understanding and measuring conditions of trust: evolution of a conditions of trust inventory. Journal of Management 17:643-663

Citrin J, Muste C (1999) Trust in government. In: Robinson JP, Shaver PR, Wrightsman LS (eds) Measures of political attitudes. Academic Press, San Diego, CA, pp 465-532

Cohen JD (2000) Preventing disaster: home ignitability in the wildland-urban interface. Journal of Forestry 98(3):15-21

Cook J, Wall T (1980) New work attitude measure of trust, organizational commitment, and personal need nonfulfillment. Journal of Occupational Psychology 53(1):39-52

Curtin R, Presser S, Singer E (2005) Changes in telephone survey nonresponse over the past quarter century. Public Opinion Quarterly 69:87-98

Cvetkovich G, Winter PL (2003) Trust and social representations of the management of threatened and endangered species. Environment and Behavior 35:286-307

Cvetkovich GT, Winter PL (2004) Seeing eye-to-eye on natural resource management: trust, value similarity, and action consistency/justification. In: Proceedings of the fourth social aspects and recreation research symposium, San Francisco State University, San Francisco, February 4-6, pp 47-50

Davenport MA, Leahy JE, Anderson DH, Jakes PJ (2007) Building trust in natural resource management: a case study of the Midewin National Tallgrass Prairie. Environmental Management 39:353-368

Deutsch M (1960) The effect of motivational orientation upon trust and suspicion. Human Relations 13:123-140

Dillman DA (2007) Mail and Internet surveys: the tailored design method, 2nd edn. 2007 update. Wiley, Hoboken, NJ

Earle TC, Cvetkovich GT (1995) Social trust: toward a cosmopolitan society. Praeger, Westport, CT

Farris G, Senner E, Butterfield D (1973) Trust, culture, and organizational behavior. Industrial Relations 12:144-157

Fukuyama F (1995) Trust. Free Press, New York

Gabarro J (1978) The development of trust, influence, and expectations. In: Athos AG, Gabarro JJ (eds) Interpersonal behavior: communication and understanding in relationships. Prentice Hall, Englewood Cliffs, NJ, pp 290-303 
Ganesan S, Hess R (1997) Dimensions and levels of trust: implications for commitment to a relationship. Marketing Letters 8:439448

Giffin K (1967) The contribution of studies of source credibility to a theory of interpersonal trust in the communication department. Psychological Bulletin 68:104-120

Good D (1988) Individuals, interpersonal relations, and trust. In: Gambetta DG (ed) Trust. Basil Blackwell, New York, pp 131185

Hair JF, Anderson RE, Tatham RL, Black WC (1998) Multivariate data analysis, 5th edn. Prentice Hall, Upper Saddle River, NJ

Hardin R (1993) The street-level epistemology of trust. Politics and Society 21:505-529

Hart KM, Capps HR, Cangemi JP, Canillouet LM (1986) Exploring organizational trust and its multiple dimensions: a case study of General Motors. Organization Development Journal 4:31-39

Hovland CI, Janis IL, Kelly HH (1953) Communication and persuasion. Yale University Press, New Haven, CT

Hu L-t, Bentler P (1999) Cutoff criteria for fit indexes in covariance structure analysis: conventional criteria versus new alternatives. Structural Equation Modeling 6:1-55

Institute for Social Research (1999) 1999-2000 World Values Survey Questionnaire. Available at: http://wvs.isr.umich.edu/wvs 2000.doc/. Accessed July 7, 2003

Johnson BB (1999) Exploring dimensionality in the origins of hazardrelated trust. Journal of Risk Research 2:325-354

Johnson-George C, Swap W (1982) Measurement of specific interpersonal trust: Construction and validation of a scale to assess trust in a specific other. Journal of Personality and Social Psychology I 43:1306-1317

Jones AP, James LR, Bruni JR (1975) Perceived leadership behavior and employee confidence in the leader as moderated by job involvement. Journal of Applied Psychology 60:146-149

Kee HW, Knox RE (1970) Conceptual and methodological considerations in the study of trust and suspicion. Journal of Conflict Resolution 14:357-366

Kish L (1949) A procedure for objective respondent selection within the household. Journal of the American Statistical Association 44:380-387

Kline RB (2005) Principles and practice of structural equation modeling, 2nd edn. Guilford, New York

Knotek K, Watson AE (2006) Organizational characteristics that contribute to success in engaging the public to accomplish fuels management at the wilderness/non-wilderness interface. In: Andrews PL, Butler BW (comps.) (eds) Fuels managementhow to measure success: conference proceedings. 2006 28-30 March; Portland, OR. Proceedings RMRS-P-41. U.S. Department of Agriculture, Forest Service, Rocky Mountain Research Station, Fort Collins, CO, pp 703-713

Kramer R (1999) Trust and distrust in organizations: emerging perspective, enduring questions. Annual Review of Psychology 50:569-598

Lachapelle PR, McCool SF, Patterson ME (2003) Barriers to effective natural resource planning in a "messy" world. Society and Natural Resources 16:473-490

Larzelere R, Huston T (1980) The dyadic trust scale: toward understanding interpersonal trust in close relationships. Journal of Marriage and the Family 42:595-604

Leahy JE, Davenport MA, Anderson DA, Jakes PJ (2004) Community trust in natural resource agencies: case studies from Illinois. In: Proceedings of the fourth social aspects and recreation research symposium; 2004 February 4-6; San Francisco State University, San Francisco, pp 51-57

Levi M (1998) A state of trust. In: Braithwaite V, Levi M (eds) Trust and governance. Russell Sage Foundation, New York, pp 77-101
Levi M (2000) When good defenses make good neighbors. In: Menard C (ed) Institutions, contracts, and organizations: perspectives from new institutional economics. Edward Elgar, Chichester, UK, pp 137-157

Lieberman JK (1981) The litigious society. Basic Books, New York

Liljeblad A, Borrie WT, Watson AE (2005) Monitoring trust as an evaluation of the success of collaborative planning the a landscape-level fuel hazard reduction treatments project in the Bitterroot Valley, Montana. Final report. Unpublished manuscript. University of Montana

Mason WM, House JS, Martin SS (1985) On the dimensions of political alienation in America. Sociological Methodology 15:111-151

Mayer RC, Davis JH, Schoorman FD (1995) An integrative model of organizational trust. Academy of Management Review 20:709734

Miller AH (1974) Political issues and trust in government: 19641970. American Political Science Review 68:951-972

Mishra AK (1996) Organizational responses to crisis: the centrality of trust. In: Kramer RM, Tyler T (eds) Trust in organizations. Sage, Newbury Park, CA, pp 261-287

Morgan RM, Hunt SD (1994) The commitment-trust theory of relationship marketing. Journal of Marketing 58:20-38

Peters RG, Covello VT, McCallum DB (1997) Determinants of trust and credibility in environmental risk assessment: an empirical study. Risk Analysis 17:43-54

Ring SM, Van de Ven A (1992) Structuring cooperative relationships between organizations. Strategic Management Journal 13:483498

Rosen B, Jerdee TH (1977) Influence of subordinate characteristics on trust and use of participative decision strategies in a management simulation. Journal of Applied Psychology 62:628-631

Rousseau DM, Sitkin SB, Burt RS, Camerer C (1998) Not so different after all: a cross discipline view of trust. Academy of Management Review 23:393-404

Schumaker RE, Lomax RG (2004) A beginner's guide to structural equation modeling, 2nd edn. Lawrence Erlbaum Associates, Mahwah, NJ

Sheppard BH, Sherman DM (1998) The grammars of trust: a model and general implications. Academy of Management Review 23:422-437

Shindler BA, Toman E (2003) Fuel reduction strategies in forest communities: a longitudinal analysis of public support. Journal of Forestry 101:8-15

Shindler BA, Brunson M, Stankey GH (2002) Social acceptability of forest conditions and management practices: a problem analysis. Gen. Tech. Rep. PNW-GTR-537. U.S. Department of Agriculture, Forest Service, Pacific Northwest Research Station, Portland, OR

Sitkin SB, Roth NL (1993) Explaining the limited effectiveness of legalistic "remedies" for trust/distrust. Organization Science 4:367-392

Sjöberg L (2001) Limits of knowledge and the limited importance of trust. Risk Analysis 21:189-198

Solomon L (1960) The influence of some types of power relationships and game strategies upon the development of interpersonal trust. Journal of Abnormal and Social Psychology 61:223-230

Strickland LH (1958) Surveillance and trust. Journal of Personality 26:200-215

Sudman S, Bradburn NM, Schwartz N (1995) Thinking about answers: the application of cognitive processes to survey methodology. Jossey-Bass, San Francisco

Thomas CW (1998) Maintaining and restoring public trust in government agencies and their employees. Administration and Society 30:166-194 
Van den Bos K, Wilke HAM, Lind EA (1998) When do we need procedural fairness? The role of trust in authority. Journal of Personality and Social Society 75:1449-1458

Weick KE, Sutcliffe KM (2001) Managing the unexpected: assuring high performance in an age of complexity. Wiley, San Francisco

Winter PL, Cvetkovich GT (2003) A study of Southwesterners' opinions on the management of wildland and wilderness firesfire management version. Unpublished report. Pacific Southwest Research Station. USDA Forest Service, Riverside, CA
Winter PL, Palucki LJ, Burkhardt RL (1999) Anticipated responses to a fee program: the key is trust. Journal of Leisure Research 3:207-226

Winter GJ, Vogt CA, Fried JS (2002) Fuel treatments at the wildland urban interface: common concerns in diverse regions. Journal of Forestry 100:15-21

Winter G, Vogt CA, McCaffrey S (2004) Examining social trust in fuels management strategies. Journal of Forestry 102:8-15 